\title{
Hubungan BRAF V600E dan EGFR dengan Metastasis ke Kelenjar Getah Bening pada Adenokarsinoma Kolorektal
}

\author{
Fenny Ariyanni, ${ }^{1}$ Abdul Hadi Hassan, ${ }^{2}$ Bethy S. Hernowo ${ }^{2}$ \\ ${ }^{1}$ Rumah Sakit Santosa Kopo Bandung, ${ }^{2}$ Departemen Patologi Anatomi Fakultas Kedokteran Universitas \\ Padjadjaran/Rumah Sakit Dr. Hasan Sadikin Bandung
}

\begin{abstract}
Abstrak
Adenokarsinoma kolorektal adalah tumor ganas epitel kolorektal yang berdiferensiasi kelenjar. Metastasis ke kelenjar getah bening sangat memengaruhi prognosis dan penatalaksanaan penderita karsinoma kolorektal. Penelitian ini untuk mengetahui hubungan BRAF V600E dan EGFR dengan metastasis ke kelenjar getah bening. Disain penelitian potong lintang analisis kategorik tidak berpasangan terhadap kasus adenokarsinoma kolorektal yang dipilih secara konsekutif dari blok parafin massa tumor yang dilakukan pemeriksaan imunohistokimia $B R A F$ V600E dan EGFR di Departemen Patologi Anatomi Fakultas Kedokteran Universitas Padjadjaran/RSUP Dr. Hasan Sadikin Bandung pada bulan Februari sampai Juni 2014. Hasil penelitian menunjukkan tidak terdapat hubungan antara imunoekspresi BRAF V600E positif dan metastasis ke kelenjar getah bening dengan p=0,269 (uji chikuadrat) dan imunoekspresi EGFR yang positif dengan metastasis ke kelenjar getah bening dengan $\mathrm{p}=0,713$ (uji chi-kuadrat). Imunoekspresi BRAF V600E dan EGFR yang positif tidak berhubungan dengan metastasis ke kelenjar getah bening, p=0,427 (Uji Fisher Exact). BRAF dan EGFR berperan pada epithelial mesencymal transition sehingga sel mampu bermigrasi, tetapi kemampuan migrasi ini tidak berperan pada kejadian metastasis tumor adenokarsinoma kolorektal ke kelenjar getah bening. Simpulan, imunoekspresi BRAF V600E dan EGFR pada adenokarsinoma kolorektal tidak dapat digunakan sebagai petanda agresivitas tumor adenokarsinoma kolorektal. [MKB. 2015;47(3):179-85]
\end{abstract}

Kata kunci: Adenokarsinoma, BRAF V600E, EGFR, kelenjar getah bening, kolorektal

\section{Association of BRAF V600E and EGFR with Lymph Nodes Metastasis in Colorectal Adenocarcinoma}

\begin{abstract}
Colorectal adenocarcinoma is an epithelial malignant tumor with glandular differentiation. Lymph node metastasis affects the prognosis and management of colorectal carcinoma patients. In this study, association of BRAF V600E and EGFR with metastasis of the lymph nodes was investigated. This was a cross sectional study with unpaired categorical analysis of colorectal adenocarcinoma obtained from archival paraffin blocks from consecutively selected samples. The blocks were stained by BRAF V600E and EGFR antibodies at the Department of Anatomical Pathology, Faculty of Medicine, Universitas Padjadjaran/Dr. Hasan Sadikin General Hospital during the period of February to June 2014. There was no association between positive BRAF V600E immunoexpression and lymph node metastasis, $p=0.269$ ( $p>0.05$, chi-square test). Similarly, there was no association between positive EGFR immunoexpression and lymph node metastasis, $p=0.713$ ( $p>0.05$, chi-square test). Positive BRAF V600E immunoexpresion and positive EGFR immunoexpression also had no association with lymph node metastasis, $\mathrm{p}=0.427$ (Fisher Exact test). BRAF and EGFR may play a role in the epithelial mesenchymal transition to increase cell migration and invasion. However, in colorectal adenocarcinoma, BRAF V600E and EGFR were not associated with lymph node metastasis. In conclusions, positive BRAF V600E immunoexpression and positive EGFR immunoexpression in colorectal adenocarcinoma should not be used as markers for the metastazing potentials of colorectal adenocarcinoma tumors. [MKB. 2015;47(3):179-85]
\end{abstract}

Key words: Adenocarcinoma, BRAF V600E, colorectal, EGFR, lymph node

Korespondensi: Fenny Ariyanni, dr., Sp.PA., M. Kes, Rumah Sakit Santosa Kopo Bandung, Jalan K.H. Wahid Hasyim No. 461-463 Kopo Bandung, mobile 08122136532, e-mail: fennyariyanni@yahoo.com 


\section{Pendahuluan}

Adenokarsinoma kolorektal adalah tumor ganas dari epitel kolorektal yang memiliki diferensiasi kelenjar. ${ }^{1}$ Prognosis pada penderita karsinoma kolorektal akan sangat menurun ketika tumor telah bermetastasis pada kelenjar getah bening dan stadium tumor saat pertama kali didiagnosis merupakan faktor untuk prognosis yang utama, juga akan memengaruhi manajemen terapi penderita. Pengetahuan tentang mekanisme molekuler metastasis ke kelenjar getah bening akan menjadi strategi bagi pengobatan tumor adenokarsinoma kolorektal di masa depan. ${ }^{2}$

The College of American Pathologists (CAP) dan the National Comprehensive Cancer Network (NCCN) telah merekomendasikan pemeriksaan kelenjar getah bening minimal 12 buah untuk dapat menegakkan stadium tumor karsinoma kolorektal. ${ }^{3}$ Berdasarkan atas penelitian dari database kanker nasional Amerika Serikat yang mengevaluasi tindakan kolektomi yang dilakukan di 1.300 rumah sakit, dilaporkan bahwa lebih dari $60 \%$ rumah sakit tersebut tidak berhasil memeriksa kelenjar getah bening sebanyak minimal 12 buah. ${ }^{4}$ Tampaknya kegagalan tersebut disebabkan oleh karsinogenesis merupakan proses yang multitahap dan kompleks yang melibatkan sistem limfatik sebagai salah satu jalur dalam progresivitas kanker. ${ }^{2}$

Epithelial-mesenchymal transition (EMT) dan mesenchymal-epithelial transition (MET) adalah perubahan fenotipe antara epitel dan mesenkim. Epithelial-mesenchymal transition atau EMT merupakan suatu langkah awal karsinoma kolorektal memperoleh kemampuan untukdapat migrasi dan invasi. ${ }^{5}$ Mutasi gen BRAF dapat memengaruhi pengorganisasian sitoskeleton dan migrasi sel serta kemampuan invasi melalui Rho family GTPases yang akan memengaruhi perubahan adhesi sel, matriks sel, interaksi sel, dan pengorganisasian aktin yang pada akhirnya sel akan mendapatkan fenotipe yang bersifat invasif. $B R A F$ juga terlibat dalam EMT., ${ }^{6,7}$

Gen epidermal growth factor receptor (EGFR) adalah human epidermal receptor (HER) tyrosine kinase growth factor receptor yang memiliki berat molekul 170 kDalton. ${ }^{8}$ Epidermal growth factor (EGF) dapat menstimulasi migrasi sel epitel sehingga ligan EGF dan reseptornya terlibat dalam proses metastasis. ${ }^{9}$ EGFR juga berhubungan dengan inisiasi epithel-mesenchymal transition (EMT) atau induksi neoangiogenesis tumor. ${ }^{9}$ Epidermal growth factor receptor (EGFR) akan meningkatkan kemampuan migrasi sel melalui pengaturan matriks metaloproteinase yang akan memengaruhi ikatan antarsel. Epidermal growth factor receptor juga memengaruhi proliferasi sel dan akan merangsang pembentukan pembuluh darah baru untuk menyediakan kebutuhan metabolisme sel dan oksigenasi. ${ }^{7}$

Untuk mengetahui hubungan protein BRAF V600E dan EGFR dengan kejadian metastasis ke kelenjargetah beningdaritumoradenokarsinoma kolorektal, dilakukan penelitian dengan harapan dapat mengungkapkan peran gen BRAF V600E dan EGFR pada metastasis sebagai petanda agresivitas tumor adenokarsinoma kolorektal.

\section{Metode}

Objek penelitian ini adalah blok parafin massa tumor penderita adenokarsinoma kolorektal yang telah dilakukan operasi dan didiagnosis secara histopatologi sebagai adenokarsinoma kolorektal dengan jumlah kelenjar getah being yang ditemukan sebanyak minimal 12 buah, serta data rekam medisnya tersedia. Objek penelitian dipilih secara konsekutif dengan kesalahan tipe $\mathrm{I}=5 \%$ dan $\mathrm{Z} \dot{\alpha}=1,64$, kesalahan tipe $\mathrm{II}=20 \% \mathrm{Z} \beta=1,28$, dan $\mathrm{P}_{2}$ adalah 0,1 dan $\mathrm{P}_{1}$ adalah 0,59 sehingga didapatkan jumlah sampel minimal 15 buah.

Disain penelitian ini adalah potong lintang dengan analisis kategorik tidak berpasangan untuk mencari hubungan variabel bebas (imunoekspresi BRAF V600E dan EGFR) dengan variabel tergantung (status metastasis kelenjar getah bening). Imunoekspresi BRAF V600E ditentukan berdasarkan atas sitoplasma yang terpulas oleh antibodi BRAF V600E klon VE1 menjadi berwarna coklat. Tumor dikatakan positif bila lebih dari $20 \%$ sel tumor terpulas antibodi BRAF V600E klon VE1 dan dikatakan negatif bila kurang atau sama dengan $20 \%$ sel tumor terpulas antibodi BRAF V600E klon VE1 (Gambar 1). ${ }^{10}$ Kontrol positif menggunakan karsinoma papilari tiroid. Semua tumor diperiksa tanpa mengetahui genotipe tumor tersebut.

Imunoekspresi EGFR dinilai berdasarkan terpulasnya membran sel dan sedikit sitoplasma di daerah dekat membran sel oleh antibodi $E G F R$ klon H11 menjadi berwarna coklat. Kontrol positif yang digunakan adalah karsinoma sel skuamousa paru. Kontrol negatif yang digunakan adalah sentrum germinal tonsil.

Tumor dikatakan positif bila lebih dari 10\% sel tumor terwarna antibodi EGFR klon H11 dan dikatakan negatif bila kurang atau sama dengan $10 \%$ sel tumor terwarna antibodi EGFR klon H11 (Gambar 2). ${ }^{11}$ 


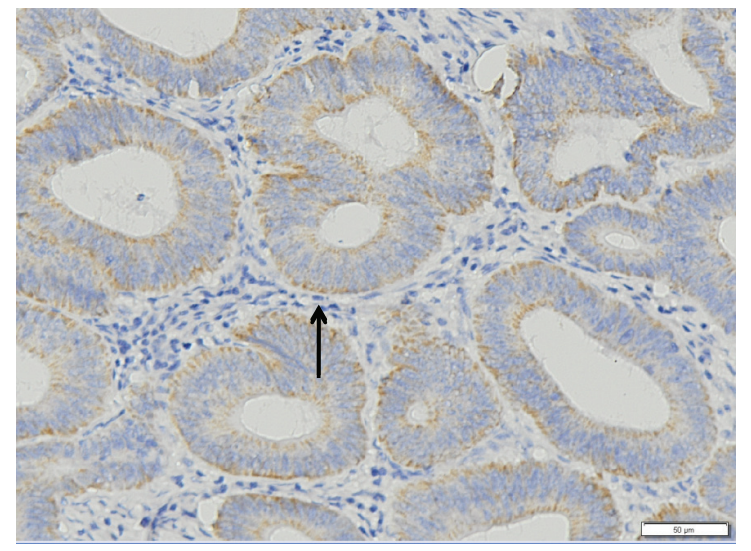

\section{Gambar 1 Hasil Pewarnaan Antibodi BRAF V600E yang Positif (Pembesaran 200x) \\ Keterangan: tanda panah menunjukkan sitoplasma sel tumor terpulas antibodi $B R A F$ V600E menjadi berwarna coklat}

Metastasis pada kelenjar getah bening ditentukan daripemeriksaan mikroskopis dengan pewarnaan hematoxylin eosin. Status metastasis kelenjar getah bening disebut metastasis bila ditemukan sel tumor adenokarsinoma pada sediaan mikroskopis kelenjar getah bening yang sama seperti sel tumor primernya dan terpisah dari tumor primernya (Gambar 3). ${ }^{12}$

Semua sediaan hematoxylin eosin diperiksa kembali dan juga dilakukan penilaian status metastasis kelenjar getah bening dan dipilih blok parafin massa tumor yang representatif, dilakukan pemotongan serial blok parafin 4 $\mu \mathrm{m}$ dan ditempel pada kaca objek yang sudah dilakukan coating serta dipulas dengan antibodi BRAF V600E klon VE1 dan EGFR klon H11 dengan teknik pulasan imunohistokimia labeled streptavidin/streptavidin-biotin (LSAB).

Cara pulasan imunohistokimia BRAF V600E: setelah dilakukan deparafinisasi dan dehidrasi, dilakukan proses heat induced antigen retrieval, ditetesi blocking serum, dibilas PBS secara sekuensial, dan diteteskan mouse antihuman BRAF V600E antibodi monoklonal (klon VE1) (Spring Bioscience) dengan pengenceran 1:200. Sesudah itu, dilakukan inkubasi semalam, dibilas PBS diberi antibodi sekunder Trekkie universal link (Biocare Medical), dibilas PBS, dilabel TrekAvidin HRP, ditetes larutan kromogen betazoid $D A B$, dicuci air mengalir, dan dilakukan counterstain dengan hematoxylin Mayer. Cara pulasan imunohistokimia EGFR sama dengan BRAF V600E, antibodi yang digunakan mouse monoclonal antihuman EGFR (klon H11) dari

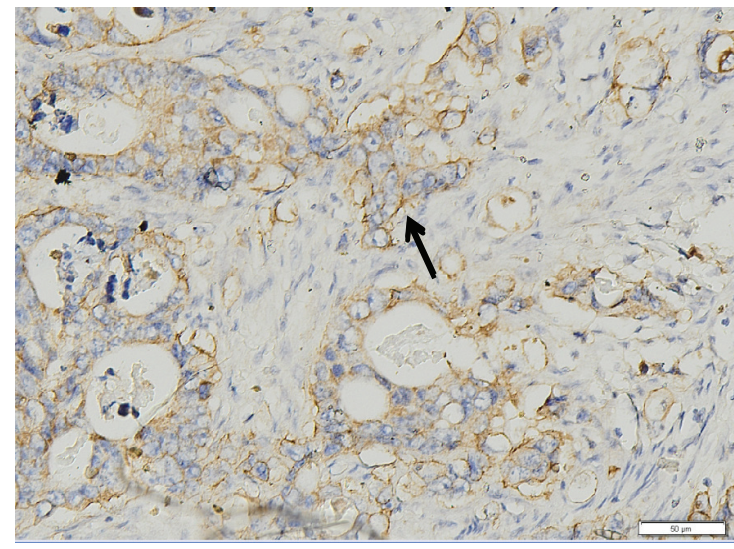

\section{Gambar 2 Hasil Pewarnaan Antibodi EGFR yang Positif (Pembesaran 200x) \\ Keterangan: tanda panah menunjukkan membran dan sedikit sitoplasma sel tumor terpulas antibodi EGFR menjadi berwarna coklat}

DAKO dengan pengenceran 1:200, tetapi pada proses antigen retrieval dipergunakan enzim carezyme iii pronase kit (PRT $957 \mathrm{Kh}$ ) dengan pengenceran 1:4. Data penelitian berupa data kategorik tidak berpasangan, analisis yang dipergunakan uji chi-kuadrat dengan tingkat signifikan 5\% menggunakan program SPSS versi 20.

\section{Hasil}

Bahan yang dipergunakan pada penelitian ini adalah blok parafin penderita yang didiagnosis secara histopatologis sebagai adenokarsinoma

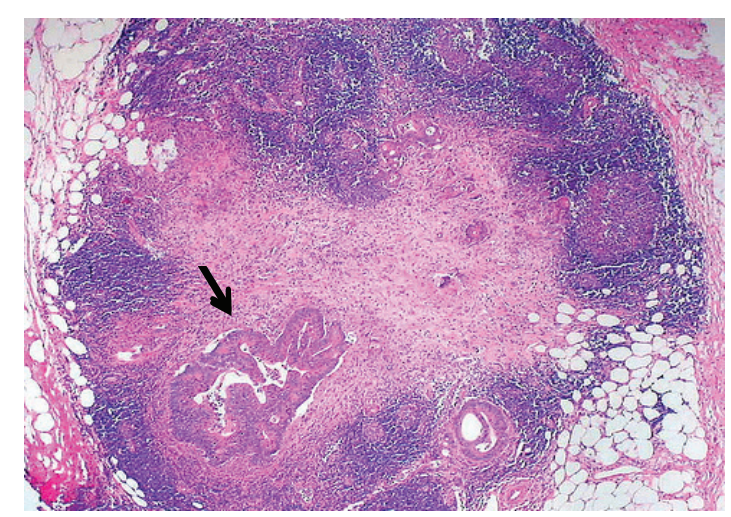

Gambar 3 Metastasis Adenokarsinoma Kolon pada Kelenjar Getah Bening (Pewarnaan HE, Pembesaran 200x) Keterangan: tanda panah menunjukkan metastasis sel tumor adenokarsinoma kolorektal ke kelenjar getah getah bening 
Tabel 1 Karakteristik Subjek Penelitian Adenokarsinoma Kolorektal

\begin{tabular}{|c|c|c|c|}
\hline Variabel & $\begin{array}{l}\text { Tidak Metastasis } \\
\text { (n=15) }\end{array}$ & $\begin{array}{c}\text { Metastasis } \\
(n=15)\end{array}$ & $\mathbf{n}=\mathbf{3 0}$ \\
\hline \multicolumn{4}{|l|}{ Jenis kelamin } \\
\hline Laki-laki & 12 & 9 & 21 \\
\hline Perempuan & 3 & 6 & 9 \\
\hline \multicolumn{4}{|l|}{ Usia (tahun) } \\
\hline$\leq 51$ & 6 & 8 & 14 \\
\hline$>51$ & 9 & 7 & 16 \\
\hline \multicolumn{4}{|l|}{ Usia rata-rata 51,4 tahun } \\
\hline \multicolumn{4}{|c|}{ Standar deviasi $(\mathrm{SD})=12,8$ tahun } \\
\hline \multicolumn{4}{|l|}{ Lokasi } \\
\hline Kolon kanan & 9 & 3 & 12 \\
\hline Kolon transversum & 1 & 1 & 2 \\
\hline Kolon kiri & 1 & 0 & 1 \\
\hline Kolon sigmoid & 1 & 2 & 3 \\
\hline Rektum & 3 & 9 & 12 \\
\hline \multicolumn{4}{|l|}{ Diferensiasi } \\
\hline Baik & 11 & 8 & 19 \\
\hline Sedang & 2 & 7 & 9 \\
\hline Buruk & 2 & 0 & 2 \\
\hline
\end{tabular}

kolorektal dan dipilih kasus yang memiliki data operasi lengkap, jumlah kelenjar getah bening yang ditemukan sebanyak 12 buah, dan blok parafin dengan massa tumor yang adekuat. Karakteristik subjek penelitian ini terbanyak ditemukan pada jenis kelamin laki-laki, dengan usia lebih dari 51 tahun, dan lokasi terbanyak pada kolon kanan, serta derajat diferensiasi tumor yang terbanyak adalah derajat diferensiasi baik (Tabel 1). Hubungan antara imunoekspresi BRAF V600E dengan terdapat metastasis ke kelenjar getah bening dan hubungan antara imunoekspresi EGFR dengan ada metastasis ke kelenjar getah bening (Tabel 2). Hasil uji statistik menggunakan uji Chi-Square didapatkan nilai $\mathrm{p}$ $>0,05$, dan didapatkan simpulan bahwa tidak terdapat hubungan antara imunoekspresi EGFR dengan metastasis ke kelenjar getah bening. Proporsi imunoekspresi BRAF V600E dan EGFR yang keduanya positif dan proporsi imunoekspresi BRAF V600E dan imunoekspresi EGFR yang salah satu positif atau keduanya negatif dengan terdapat metastasis ke kelenjar getah bening (Tabel 3).

Tabel 2 Perbandingan Imunoekspresi pada Adenokarsinoma Kolorektal

\begin{tabular}{lcccc}
\hline \multicolumn{1}{c}{ Imunoekspresi } & $\begin{array}{c}\text { Tidak Metastasis } \\
(\mathbf{n = 1 5})\end{array}$ & $\begin{array}{c}\text { Metastasis } \\
(\mathbf{n = 1 5})\end{array}$ & $\mathbf{n = 3 0}$ & Statistik \\
\hline BRAF V600E & 8 & & 13 & $\mathrm{p}=0,269^{*}$ \\
$\quad$ Negatif & 7 & 5 & 17 & \\
$\quad \begin{array}{l}\text { Positif } \\
\text { EGFR }\end{array}$ & & 10 & & $\mathrm{p}=0,713^{*}$ \\
$\quad$ Negatif & 8 & 9 & 17 & 13 \\
$\quad$ Positif & 7 & 6 & & \\
\hline
\end{tabular}

Keterangan: *Menggunakan uji chi-kuadrat didapatkan nilai $\mathrm{p}>0,05$, hasil uji statistik tidak bermakna 
Tabel 3 Perbandingan Proporsi Imunoekspresi BRAF V600E dan EGFR Positif dengan Salah Satu atau Kedua Hasil Imunoekspresi Negatif pada Adenokarsinoma Kolorektal

\begin{tabular}{|c|c|c|c|c|}
\hline $\begin{array}{c}\text { Hasil Imunoekspresi BRAF } \\
\text { V600E dan EGFR }\end{array}$ & $\begin{array}{l}\text { Tidak Metastasis } \\
\quad(n=15)\end{array}$ & $\begin{array}{l}\text { Metastasis } \\
\quad(n=15)\end{array}$ & $n=30$ & Statistik \\
\hline Keduanya positif & 6 & 3 & 9 & $\mathrm{p}=0,427^{*}$ \\
\hline $\begin{array}{l}\text { Salah satu positif atau keduanya } \\
\text { negatif }\end{array}$ & 9 & 12 & 21 & \\
\hline
\end{tabular}

Keterangan: *Menggunakan uji chi-kuadrat didapatkan nilai $\mathrm{p}>0,05$, hasil uji statistik tidak bermakna

\section{Pembahasan}

Karsinoma kolon diklasifikasikan berdasarkan kriteria klinis dan histopatologi. Prognosis dan terapi berhubungan erat dengan klasifikasi tersebut. Tipe histopatologi yang paling sering adalah adenokarsinoma. ${ }^{1}$ Karakteristik usia subjek penelitian yaitu usia rata-rata penderita 51,4 tahun (standar deviasi/SD=12,8 tahun). Penelitian yang dilakukan Lukman dkk. ${ }^{13}$ yaitu mendapatkan proporsi penderita adenokarsinoma kolorektal di Rumah Sakit Dr. Hasan Sadikin Bandung dalam periode Maret 2009-Maret 2010 diperoleh 17 penderita berusia lebih dari 40 tahun dan 22 penderita berusia kurang atau sama dengan 40 tahun.

Pada penelitian ini, kasus adenokarsinoma kolorektal lebih banyak ditemukan pada lakilaki, yaitu 21 kasus dan perempuan 9 kasus atau rasio laki-laki banding perempuan adalah 2,3:1. Penelitian Lukman dkk. ${ }^{13}$ juga mendapatkan penderita adenokarsinoma kolorektal laki-laki lebih banyak daripada perempuan yaitu 21 penderita laki-laki dan 18 penderita perempuan.

Hasil penelitian ini memperlihatkan temuan bahwa imunoekspresi BRAF V600E pada adenokarsinoma kolorektal tidak berhubungan dengan terdapatnya metastasis ke kelenjar getah bening. Hasil ini sesuai dengan hasil penelitian Li dkk. ${ }^{14}$ yang meneliti hubungan mutasi KRAS, $B R A F$, dan PIK3CA pada karsinoma kolorektal dengan metastasis karsinoma kolorektal. Hasil penelitian $\mathrm{Li}$ dkk. ${ }^{14}$ tidak terdapat hubungan antara mutasi gen BRAF dan stadium Dukes (A, $\mathrm{B}, \mathrm{C}, \mathrm{D})$ pada karsinoma kolorektal dengan hasil uji statistik chi-kuadrat $(p=0,1116)$. Li dkk. ${ }^{14}$ dalam penelitiannya mempergunakan metode genomic DNA extraction dan pyrosequencing untuk mendeteksi mutasi gen $B R A F$.

Penelitian yang dilakukan oleh Pai dkk. ${ }^{15}$ didapatkan mutasi gen BRAF berhubungan dengan lokasi adenokarsinoma kolon kanan dengan mismatch repair DNA dan memiliki tampilan klinis yang buruk serta menunjukkan diferensiasi histologi musinus dan signet ring. Gambaran histologi berupa invasi kelenjar getah bening dan perineural. Pada penelitian ini semua sampel karsinoma kolorektal yang digunakan adalah varian adenokarsinoma (NOS) sehingga mungkin keadaan ini yang dapat menyebabkan perbedaan hasil penelitian ini dengan penelitian yang dilakukan Pai dkk. Lokasi terbanyak pada kolon kanan (12/30) dan rektum (12/30).

Affolter dkk. ${ }^{16}$ telah meneliti sensitivitas dan juga spesifisitas pemeriksaan pulasan imunohistokimia BRAF V600E terhadap pemeriksaan pyrosequencing. Hasil sensitivitas dan spesifisitas pulasan imunohistokimia BRAF V600E adalah $100 \%$.

Saat ini diketahui ada 30 macam mutasi gen $B R A F$ yang telah teridentifikasi dan gen $B R A F$ V600E meliputi $90 \%$ dari seluruh mutasi $B R A F .^{17}$ Penelitian ini menggunakan metode pemeriksaan pulasan imunohistokimia untuk memeriksa mutasi BRAF V600E memakai antibodi antihuman klon VE1 yang spesifik untuk mutasi tertentu dari gen $B R A F$ (lokus V600E) sehingga hasil imunoekspresi BRAF V600E negatif tidak menutup kemungkinan mutasi pada lokus mutasi lain dari gen $B R A F$ yang lain. Direct sequencing masih merupakan standar baku emas (gold standard) untuk pemeriksaan mutasi BRAF dan salah satu keuntungan pemeriksaan squencing dibanding dengan pemeriksaan yang lain yaitu dapat mendeteksi mutasi $B R A F$ yang lain selain V600E. ${ }^{17}$

Hasil penelitian ini ternyata berbeda dengan penelitian yang telah dilakukan oleh Mokhtari dkk. ${ }^{18}$ yang mendapatkan perbedaan bermakna imunoekspresi EGFR kelompok adenokarsinoma kolorektal (stadium III) yang bermetastasis ke kelenjar getah bening dengan kelompok adenokarsinoma kolorektal yang tidak bermetastasis ke kelenjar getah bening (stadium I dan II); dengan uji chi-kuadrat dan didapatkan $p=0,01$. Perbedaan ini kemungkinan disebabkan oleh antibodi primer yang dipakai, pada penelitian yang dilakukan oleh Mokthari 
dkk. digunakan primer antibodi EGFR (RTU) produksi Novocastra. Juga terdapat perbedaan cara pelepasan antigen (antigen retrieval), yaitu menggunakan larutan proteinase $\mathrm{K}$ selama 40 menit dan inkubasi menggunakan polimer $E n$ Vision selama 30 menit, sedangkan sistem skor penilaian imunoekspresi EGFR berbeda dengan memakai 4 kategori penilaian. Pada penelitian ini menggunakan antibodi primer EGFR klon H11 produksi Dako, carezyme III pronase kit selama 15 menit dan memakai blocking serum selama 10 menit, hanya menggunakan 2 kategori penilaian imunoekspresi EGFR.

Imunohistokimia sering dipergunakan untuk diagnosis klinis dan juga klasifikasi neoplasma. Saat ini belum terdapat panduan standardisasi yang telah diterima secara luas. Variasi pada tahapan preanalisis, analisis, dan postanalisis ternyata imunohistokimia merupakan faktor yang menurunkan reproduksibilitas meliputi preparasi jaringan, fiksasi, reagen yang berbeda, perbedaan metode pewarnaan, sistem skor, dan definisi hasil positif. Ekspresi EGFR sangat bergantung terhadap tipe antibodi, protokol pemeriksaan, sistem skor, dan juga cut-off yang digunakan. ${ }^{19}$ EGFR antibodi klon $\mathrm{H} 11$ dapat mendeteksi molekul seberat $170 \mathrm{kDa}$ pada sel A431 dan sel MB-468, juga mendeteksi molekul seberat 140kDa pada sel H1666. Klon H11 juga dapat mengenali epitop domain ekstraseluler protein EGFR. ${ }^{19}$

Metastasis difasilitasi oleh interaksi antarsel dengan sel-sel tumor dan endotel di jaringan yang jauh. Sel tumor di dalam sirkulasi juga berinteraksi dengan trombosit dan leukosit yang akan berkontribusi terhadap adhesi sel tumor, ekstravasasi, dan terbentuknya lesi metastasis. Proses metastasis merupakan rangkaian proses yang saling memengaruhi berupa invasi lokal sel tumor pada tumor, kemampuan bertahan hidup dalam sirkulasi sistemik, melakukan ekstravasasi ke tempat sekunder, dan pada akhirnya terbentuk lesi metastasis. Kapasitas metastasis sel tumor berhubungan dengan kemampuan untuk keluar dari sirkulasi darah membentuk koloni di lokasi yang jauh dari sel tumor primer dan bertumbuh di lokasi tersebut. ${ }^{20}$

Simpulan, EGFR dan juga BRAF walaupun terlibat dalam proses migrasi sel dan adhesi sel yang berkontribusi terhadap metastasis, tetapi tidak berhubungan dengan status metastasis. Hal ini kemungkinan disebabkan oleh proses metastasis tersebut masih melibatkan banyak sekali mutasi gen-gen lain yang lebih berperan sehingga perlu dilakukan penelitian terhadap gen lain yang berperan pada kejadian metastasis.

\section{Daftar Pustaka}

1. Hamilton SR, Bosman F, Boffeta P, Ilyas M, Morreau H, Nakamura S-I, dkk. Carcinoma of the colon and rectum. Dalam: Bosman FT, Carneiro F, Hruban R, Theise ND, penyunting. World Health Organization classification of tumours of the digestive system. Edisi ke-4. Lyon: IARC Press; 2010. hlm. 134-46.

2. Langheinrich MC, Schellerer V, Oeckl K, Stürzl M, Naschberger E, Croner RS. Molecular mechanisms of lymphatic metastasis. colorectal cancer biology - from genes to tumor [Internet]. 2012 [diunduh 2 Januari 2014]. Tersedia dari: http:// www.intechopen.com/books/colorectalcancerbiology-from-genes-to-tumor/ molecular-mechanisms-of-lymphaticmetastasis.

3. Benson $A B$, Venook AP, Bekaii-Saab T, Chan E, Chen Y-J, Choti MA, dkk. NCCN clinical practice guidelines in oncology colon cancer: National Comprehensive Cancer Network. Inc; 2014 [diunduh 12 Januari 2014]. Tersedia dari: http://www.nccn.org/ professionals/physician_gls/pdf/colon.pdf.

4. Baxter NN, Virnig DJ, Rothenberger DA, Morris AM, Jessurun J, Virnig BA. Lymph node evaluation in colorectal cancer patients: a population-based study. J Natl Cancer Inst. 2005;97(3):219-25.

5. Zhu Q-C, Gao R-Y, Wu W, Qin H-L. Epithelialmesenchymal transition and its role in the pathogenesis of colorectal cancer. Asian Pacific J Cancer Prev. 2013;14(5):2689-98.

6. Makrodouli E, Oikonomou E, Koc M, Andera L, Sasazuki T, Shirasawa S, dkk. BRAF and RAS oncogenes regulate Rho GTPase pathways to mediate migration and invasion properties in human colon cancer cells: a comparative study. Molecular Cancer. 2011;10:118.

7. Cantley L, Carpenter CL. Cell signaling. Dalam: DeVita VT, Lawrence TS, Rosenberg SA, penyunting. Devita, Hellman \& Rosenberg's cancer: principles \& practice of oncology. Edisi ke-9. Philladelphia: Lippincott Williams \& Wilkins; 2011. hlm. 751-800.

8. Shia J, Klimstra DS, Li AR, Qin J, Saltz L, Teruya-Feldstein J, dkk. Epidermal growth factor receptor expression and gene amplification in colorectal carcinoma: an immunohistochemical and chromogenic in situ hybridization study. Modern Pathol. 2005;18(10):1350-6.

9. Feigin ME, Muthuswamy SK. ErbB receptors and cell polarity: new pathways and 
paradigms for understanding cell migration and invasion. Experim Cell Research. 2009; 315(4):707-16.

10. Toon CW, Chou A, Desilva K, Chan J, Patterson J, Clarkson A, dkk. BRAFV600E immunohistochemistry in conjunction with mismatch repair status predicts survival in patients with colorectal cancer. Modern Pathol. 2014;27(5):644-50.

11. Cunningham MP, Essapen $S$, Thomas H, Green M, Lovell DP, Topham C, dkk. Coexpression of the IGF-IR, EGFR and HER-2 is common in colorectal cancer patients. Int J Oncol. 2006;28(2):329-35.

12. Stricker TP, Kumar V. Neoplasia. Dalam: Kumar V, Abbas AK, Fausto N, Aster JC, penyunting. Robbins and cotran pathologic basis of disease. Edisi ke-8. Philadelphia: Saunders Elsevier; 2010. hlm. 259-330.

13. Lukman K, Yuniasari L, Hernowo BS. Hubungan faktor risiko, status instabilitas mikrosatelit, dan ekspresi p53 dengan karsinogenesis adenokarsinoma kolorektal pada orang indonesia. MKB. 2012;44(4): 245-52.

14. Li HT, Lu YY, An YX, Wang X, Zhao QC. KRAS, BRAF and PIK3CA mutations in human colorectal cancer: relationship with metastatic colorectal cancer. Oncol Reports. 2011;25(6):1691-7.

15. Pai RK, Jayachandran P, Koong AC, Chang
DT, Kwok S, Ma L, dkk. BRAF-mutated, microsatellite-stable adenocarcinoma of the proximal colon: an aggressive adenocarcinoma with poor survival, mucinous differentiation, and adverse morphologic features. Am J Surg Pathol. 2012;36(5):744-52.

16. Affolter K, Samowitz W, Tripp S, Bronner MP. BRAF V600E mutation detection by immunohistochemistry in colorectal carcinoma. Genes Chromosomes Cancer. 2013;52(8):748-52.

17. Sharma SG, Gulley ML. BRAF mutation testing in colorectal cancer. Arch Pathol Lab Med. 2010;134(8):1225-8.

18. Mokhtari M, Ardestani MM, Movahedipour M. An immunohistochemical study of EGFR expression in colorectal cancer and its correlation with lymph nodes status and tumor grade. J Res Med Sci. 2012 ;17(8):7414.

19. Anagnostou VK, Welsh AW, Giltnane JM, Siddiqui S, Liceaga C, Gustavson M, dkk. Analytic variabilityinimmunohistochemistry biomarker studies. Cancer Epidemiol Biomarkers Prev. 2010;19(4):982-91.

20. Bendas G, Borsig L. Cancer cell adhesion and metastasis: selectins, integrins, and the inhibitory potential of heparins. Int J Cell Biol. 2012;2012:676731. 